\title{
STRATEGI PENANGANAN PAHAM KEAGAMAAN MENYIMPANG DALAM PERSPEKTIF DAKWAH \\ (Studi pada Kasus-kasus yang Ditangani MUI NTB)
}

\author{
Faizah, dan Muhammad Thohri
}

Fakultas Dakwah Universitas Islam Negeri Mataram e-mail: faizbundayada@gmail.com

\begin{abstract}
Abstrak: Majelis Ulama Indonesia (MUI) merupakan wadah berkumpulnya para ulama yang memiliki kredibilitas dan kapasitas keilmuan untuk memberikan penilaian terhadap ajaran sesat. MUI berperan menangani persoalan keummatan yang bersifat multidimensi terutama persoalan faham keagamaan. Penelitian ini merupakan field research yang termasuk dalam katagori kualitatif dengan lokus MUI provinsi Nusa Tenggara Barat (NTB). Teknik pengumpulan data menggunkanan teknik wawancara, observasi dan dokumentasi. Setelah melakukan kajian, baik melalui studi lapangan maupun studi literatur, maka dapat diambil kesimpulan: (1) Faham sesat di NTB, muncul hampir setiap tahun baik aliran transnasional yang berciri sosio-politik maupun lokal berciri sosio-ekonomis yang muncul sebagai konstruksi personal-awam melalui proses kontemplasi batin, (2) Faham sesat transnasional maupun lokal ditangani responsif secara koordinatif-tentatif oleh beberapa komisi di MUI dan kerjasama dengan jajaran pemerintah daerah maupun MUI Pusat, dan (3) Dakwah struktural yang massif dan memaksimalkan seluruh unsur MUI dan mitra kerja MUI belum digarap dengan baik dengan multipendekatan, multikanal dan professional.
\end{abstract}

Kata Kunci: strategi, faham keagamaan, menyimpang, perspektif dakwah

Title: Handling Strategies of Deviant Religious Ideology in Da'wah Perspective (Study in Cases Handled by MUI NTB)

Authors: Faizah, and Muhammad Thohri

\begin{abstract}
Indonesian Council of Ulama (MUI) is a gathering place for scholars (ulama) who bave scientific credibility and capacity to provide an assessment to the misguided doctrine. MUI bas a role in handling the community issues which have multidimensional characteristics, especially the issue of religious ideology. This research was a field research which is included in the qualitative category with the locus of the MUI in the province of West Nusa Tenggara (NTB). To collect the data and information about handling strategies of deviant religious ideology and doctrine in da'wah perspective, the researcher used three data collection techniques in this research, namely: interview, observation and documentation techniques. After conducting the research, both field studies and literature studies, it can be concluded that: (1) misguided ideology in NTB appears almost every year both transnational ideology which has socio-political characteristics and local ideology which has socio-economic characteristics which emerge as a personal-common construction through a process of spiritual contemplation. Transnational and local misguided ideologies are handled responsively and coordinative-tentative by several commissions at the MUI and they collaborate with the regional government and the Central MUI. The massive structural da'wah and maximizing all elements of the MUI and working partners of the MUI have not been done well with multi-approaches, multi-channels and professionals.
\end{abstract}

Keywords: strategy, religious ideology, deviant, da'wah perspective 


\section{Pendahuluan}

Agama merupakan pedoman hidup manusia untuk memahami diri dan lingkungannya. Agama kerap menjadi dasar kebudayaan dan peradaban sehingga manusia tentu membutuhkannnya. Munculnya paham yang menyimpang juga tidak lepas dari perkembangan sosial masyarakat yang cepat. Dalam kasus paham dan aliran dalam Islam sendiri, kemunculan paham dan aliran disebabkan oleh faktor internal dan eksternal. Faktor internal misalnya adanya perbedaan penafsiran terhadap teks-teks kitab suci dan faktor eksternal di antaranya faktor politik. Pengaruh faktor internal dan eksternal dalam melahirkan sebuah paham atau aliran dapat dilihat dalam fakta sejarah kelahiran aliran pemikiran dalam Islam.

Dalam konteks keindonesiaan, MUI merupakan lembaga yang memiliki legalitas formal menilai apakah suatu ajaran atau aliran dinyatakan menyimpang dari ajaran Islam. MUI sendiri merupakan wadah berkumpulnya para ulama yang memiliki kredibilitas dan kapasitas keilmuan untuk memberikan penilaian terhadap ajaran tertentu. Dalam kasus MUI di NTB, beberapa kasus penistaan agama, aliran dan paham keagamaan yang sesat dapat terungkap dan terselesaikan oleh MUI. Kasus paling anyar adalah kasus inkkarussunnah yang dilakukan Rumah Mengenal al-Qur'an¹ Melalui investigasi mendalam akhirnya kasus ini terbuka untuk publik.

Kasus kasus tersebut menggelitik untuk diteliti, bagaimana sesungguhnya strategi penanganan kasus aliran dan paham keagamaan dalam persepktif dakwah. Karena peneliti yakin dalam Islam atau dalam hal ini dakwah, memiliki metode dan kearifan spiritual untuk menghadapi kasus menyimpang tersebut. Dalam konteks dakwah siapapun ia, bahkan pelaku aliran sesat tetaplah objek dakwah yang harus didekati dengan hikmah (kebijaksanaan). Masalah yang dikaji adalah (1) bagaimanakah perkembangan paham keagamaan menyimpang di Nusa Tenggara Barat?; bagaimanakah strategi penanganan terhadap paham keagamaan tersebut oleh MUI NTB?; dan bagaimanakah strategi penanganan paham keagamaan tersebut dalam perspektif dakwah? Penelitian ini diharapkan dapat memberi sumbangan bagi khazanah kepustakaan khususnya di bidang Ilmu Dakwah dan bermanfaat bagi pemerintah dalam upaya memantau adanya paham dan aliran agama yang menyimpang dari ajaran Islam.

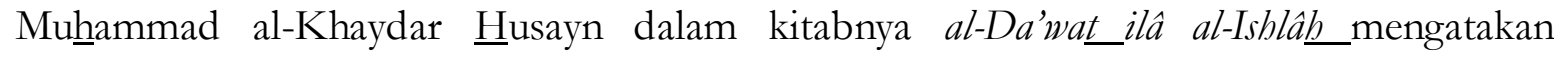
bahwa dakwah adalah mengajak kepada kebaikan dan petunjuk serta menyuruh kepada kebajikan (ma'rûf) dan melarang kepada kemungkaran agar mendapat kebahagiaan di dunia dan akhirat. ${ }^{2}$ A hlmad Ghalwâsy dalam al-Da'wat al-Islâmiyyat mendefinisikan dakwah sebagai pengetahuan yang dapat memberikan segenap usaha yang bermacam-macam yang mengacu kepada upaya penyampaian ajaran Islam kepada seluruh manusia yang mencakup akidah,

${ }^{1}$ Rumah mengenal al-Qur'an berada di jalan Bung Karno Pagesangan Timur Kecamatan Mataram di pimpin siti Aisyah. www.suarantb.com

${ }^{2}$ Muhammad al-KhaydarHusayn, al-Da'watilâ al-Islâh (Kairo: Maktabat al-Azhar, t.th), hal. 14. 
syari'at dan akhlak. ${ }^{3}$ Sedangkan Abû Bakar Zakariyyâ dalam al-Da'wat ilâ al-Islâm mendefinisikan dakwah sebagai kegiatan para ulama dengan mengajarkan manusia apa yang baik bagi mereka dalam kehidupan dunia dan akhirat menurut kemampuan mereka. ${ }^{4}$ Dari sekian definisi yang dikemukakan oleh para ulama dapat disimpulkan bahwa dakwah adalah suatu kegiatan untuk menyampaikan dan mengajarkan ajaran Islam.

Adapun kesesatan sebagai ekses menyimpangnya faham, ritual maupun ajaran telah dirumuskan kriterianya. Majelis Ulama Indonesia sebagai wadah musyawarah para ulama, zu'ama dan cendekiawan muslim berusaha untuk memberikan bimbingan dan tuntunan kepada umat Islam Indonesia dalam mewujudkan kehidupan beragama dan bermasyarakat yang diridhai Allah; memberikan nasihat dan fatwa mengenai masalah keagamaan dan kemasyarakatan kepada Pemerintah dan masyarakat, meningkatkan kegiatan bagi terwujudnya hubungan keislaman dan kerukunan antar-umat beragama dalam memantapkan persatuan dan kesatuan bangsa; menjadi penghubung antara ulama dan pemerintah dan penerjemah timbal balik antara umat dan pemerintah guna menyukseskan pembangunan nasional; dan meningkatkan hubungan serta kerjasama antar organisasi, lembaga Islam dan cendekiawan muslimin dalam memberikan bimbingan dan tuntunan kepada masyarakat khususnya umat Islam dengan mengadakan konsultasi dan informasi secara timbal balik.

\section{Metode Penelitian}

Penelitian ini merupakan field research yang termasuk dalam katagori kualitatif dengan lokus Majelis Ulama Indonesia (MUI) propinsi Nusa Tenggara Barat. Untuk mengumpulkan data dan informasi tentang strategi penanganan paham dan aliran keagamaan menyimpang dalam perspektif dakwah maka penelitian ini menggunakan tiga teknik pengumpulan data, yaitu teknik wawancara, observasi dan dokumentasi.

Wilayah jangkauan kajian ini adalah wilayah-wilayah yang terekam oleh media massa nasional maupun lokal memiliki kasus-kasus dinamika sosial keagamaan. Wilayah-wilayah yang terekam memiliki kasus dimaksud meliputi: Lombok Timur, Lombok Tengah, dan Kota Mataram. Wilayah-wilayah ini tidak dianggap mewakili trend di tingkat provinsi. Penelitian ini menganalisis trend berdasarkan kasus yang terjadi selama satu lima tahun terakhir ini.

Demi mempertimbangkan waktu, tenaga dan biaya, maka analisis data akan dilakukan dengan menggunakan teknik analisis Miles dan Huberman, yaitu analisis data dilakukan pada saat peneliti berada di lapangan. Teknik pemeriksaan atau pengecekan keabsahan data pada penelitian ini adalah perpanjangan keikutsertaan, ketekunan pengamatan, dan trianglasi.

10.

3Syekh Ahmad Ghalwâsyî, al-Da'wat al-Islâmiyyat (Kairo: Matba'at Dâr al-Kutub al-'Ilmiyyat, t.th), hal. 4Abû Bakar Zakariyyâ, al-Da'watilâ al-Islâm (Kairo: Matba'at Maktabat Dâr al-'Arûbat, 1962), hal. 8. 


\section{Hasil dan Pembahasan}

\section{Aliran Menyimpang di NTB: Dinamika Sosial Keagamaan Amaq Bakri; Nabi Pegunungan}

Salah satu keyakinan menyimpang yang timbul di wilayah hukum NTB adalah kasus nabi dari wilayah lereng Rinjani. Peladang tua mengaku menerima wangsit (wahyu) dari gaib. Media lokal maupun nasional menyorotinya. Salah satunya adalah liputan Kompas. "Amaq Bakri Mengaku Nabi, Masyarakat Resah" (Kompas.com - 16/10/2009).

Tahun 2009 Bakri Abdullah alias Amaq Bakri mengaku diri sebagai nabi. Petani dari Sambelia tersebut mengaku telah melakukan Mi'raj di hutan Gunung Rinjani. Keyakinannya tersebut disampaikan secara terbuka kepada masyarakat, meskipun terbatas kepada warga kampungnya saja. Lelaki buta huruf itu sering melakukan pertapaan di wilayah Gunung Rinjani. Meskipun tidak memiliki pengikut ajaran Amaq Bakri berbenturan dengan keyakinan mainstream sehingga menimbulkan keresahan masyarakat. Keresahan itulah yang memicu konflik yang beruntung dapat diamankan oleh Polda NTB. Jaksa mengganjar Amaq Bakri dengan hukuman satu tahun penjara.

Keyakinan Bakri dianggap bermasalah setelah ia menyatakan berniat untuk menyampaikan ajarannya kepada masyarakat dengan mahar 1.000 .000 perorang. Nama kelompok yang diandaikannya adalah Orong Kelompok Timba Gerisak. Ada pula struktur yang hendak dibuat dalam menjalankan ajarannya. Pesertanya disumpah sebelum masuk menjadi anggota. Bakri sendiri mengaku telah melalui sekolah nabi, sekaligus menjadi nabi; nabi untuk semua agama. Rekrutmen anggota dimulai dari bulan Maulid (Rabiul Awal) sampai dua bulan berikutnya. Ilmunya bernama Ilmu Macan Putih. Bakri dan ajarannya ditelusuri oleh kelompok pemuda-mahasiswa yang mencoba membongkar ajaran sesatnya.

\section{Khaerudin; Ritual Piaraan}

Ada pula faham keagamaan yang dieksprsikan melalui ritual yang menjadi pencirinya. Ajaran ini juga timbul di wilayah dusun di daerah pegunungan. Tepatnya di wilayah rendah di timur jajaran gunung Rinjani. Pencetusnya adalah orang tua yang sehari-harinya bekerja sebagai petani dengan kemampuan mengobati orang seperlunya. Tuhan diyakininya ada, namun bagimana pembuktiannya. Nah, melalui ritual itulah Sang kakek ini mencoba merumuskan cara pencapaiannya kepada Tuhan. Jamuan arak dan perempuan menjadi penciri faham sesat ini. Kontemplasi tentang Tuhan berubah menjadi "kreativitas" untuk mencapai-Nya.

MUI tidak terlibat dalam penanganan ini karena yang terlebih dahulu mencuat ke publik adalah tindakan pelaporan ke kepolisian. Laporan tersebut ditindaklanjuti secara cepat untuk mengantisipasi terjadinya hal-hal yang tidak diinginkan. Pemberitaan media massa adalah bahan informasi yang diperoleh MUI. Dalam konteks ini tentu perkara penyimpangan 
tersebut tidaklah menagih lembaga khusus untuk penanganannya mengingat hokum positif pun telah memvonis ajaran itu sebagai bentuk pelanggaran hukum positif.

\section{Siti Aisyah; Quran Sumber Ajaran Absolut!}

Suara NTB menurunkan berita dengan tajuk "Inilah Sosok Siti Aisyah, Pemilik RMA yang Diduga Sebarkan Aliran Sesat. ${ }^{5}$ Paham atau aliran yang menyimpang di wilayah Nusa Tenggara Barat bersifat personal maupun komunal. Kasus mutakhir (terakhir?) adalah sebuah gerakan yang diinisiasi oleh personal lalu membuat wadah bernama 'Rumah Mengenal AlQuran' (RMA). Rumah Mengenal al-Quran adalah rumah kediaman pemiliknya sekaligus basis gerakannya. Inti ajaran RMA adalah tidak mengakui selain al-Quran sebagai sumber ajaran. Narasi ajaran agama cukup didapatkan dari al-Quran saja. Hadits dinilainya bagian dari konstruksi sejarah. Oleh karena itu, ia menentang hadits. Modus dari pemilik keyakinan ini dalam menyebarkannya adalah dengan membagikan brosur dan pamflet kepada jamaah atau masyarakat terutama di masjid-masjid. Pelakunya berharap agar pembaca brosur dan pamflet dapat langsung belajar di rumah si pemilik ajaran.

Pemikiran kontemplatif sang ibu rumah tangga tersebut, berubah menjadi keyakinan personal yang coba diajarkan pada komunitas intelektual di Mataram. Faham ini adalah faham yang tumbuh di kalangan masyarakat urban (perkotaan) basisnya berada di jantung kota Mataram, tepatnya di jalan Bung Karno Mataram. Inilah faham atau aliran menyimpang yang terjadi di tahun 2017 di sekitar awal Januari. Siti Fatimah terang-terangan mengajak orang untuk kembali kepada Quran, meskipun ia sendiri hanya membaca terjemahnya saja.

Dilihat dari skema penanganan persoalan aliran sesat pada kasus RMA, MUI tidak secara langsung tanggap mengeluarkan fatwa terkait. MUI justru mendapatkan informasi berdasarkan pengaduan masyarakat kepada kepolisian dan terpublikasi di media massa. MUI hanya dimintai sebagai saksi ahli dalam penanganan atau proses hukum. Berbagai tindakan yang dilakukan oleh kepolisian lebih mengarah kepada upaya menjaga kamtibmas, sementara pelibatan MUI lebih kepada proses hukum dan diposisikan sebagai saksi semata. Dapat diasumsikan bahwa tindakan pihak yang berwenang lebih bersifat responsif dan kurang proaktif. Hal ini karena faham-faham menyimpang ditangani sejauh hal itu dinilai menyimpang oleh masyarakat yang ditelusuri dari laporan atau peristiwa-peristiwa terkait. Dalam konteks ini masyarakatlah yang sesungguhnya yang berperan mencegah tersebarnya faham yang menjurus kepada penyesatan ketimbang menagih peran lembaga-lembaga bentukan pemerintah semisal Majlis Ulama Indonesia.

\footnotetext{
${ }^{5}$ http://www.suarantb.com/news/2017/02/02
} 


\section{Inim alias SF; Ritual Mandi Suci}

"Diduga Ajarkan Aliran Sesat, IRT Diamankan", 15 Mei 2017, demikian berita dari Suara NTB. Di tahun 2017, tepatnya di bulan Mei muncul ajaran yang menjurus kepada penyesatan yang dilakukan oleh SF. Ia tidak memiliki kelompok maupun nama khusus untuk memberikan label pada ajarannya. Inti ajaran SF adalah adanya ritual keagamaan yang tidak lazim yang diterapkan kepada jama'ahnya. Prakteknya adalah sang murid harus membawa beberapa barang dan sejumlah uang sebagai prasyarat untuk dapat 'disucikan' dengan cara dimandikan di kamar khusus. Ritual ini digunakan agar pengikutnya patuh dan tunduk pada ajaran $\mathrm{SF}$.

Modus yang diterapkan oleh SF adalah mengajarkan langsung kepada jama'ah awam dengan sebaran sasarannya adalah masyarakat tidak terpelajar atau masyarakat yang percaya pada hal-hal mistis. Dilihat dari sifat penyebaran ajaran SF, ritual itu sesungguhnya adalah konstruk personal yang tidak terdapat pada praktek-praktek keagamaan pada kelompokkelompok tertentu. Dengan demikian, pemahaman itu lebih bersifat kontemplatif dan tidak memiliki keterkaitan dengan teks-teks atau narasi ajaran keagamaan. Lebih-lebih SF hanyalah ibu rumah tangga yang tidak secara khusus belajar agama dan tidak mengenyam pendidikan tinggi. Hal itu juga dipertegas dengan tempat tinggal SF di sebuah dusun terpencil yang relatif jauh dari akses perkotaan. Desa Sintung Lombok Tengah adalah basis ajaran SF yang tidak sempat menyebar ke kabupaten lain. SF memilih cara yang relatif tertutup dalam menjalankan misinya. Hal ini karena praktek perdukunan yang bertendensi agama memiliki penggemar khusus dan relatif rigid dalam pelaksanaannya.

Praktek ritual sesat ini ditangani oleh Kejaksaan Negeri Lombok Tengah setelah adanya laporan dari pengawasan aliran kepercayaan masyarakat (PAKEM) Lombok Tengah. Tindakan yang dilakukan adalah mediasi. MUI Lombok Tengah tidak muncul dalam pelurusan akidah karena penanganan oleh kejaksaan tidak pada ranah hukum Islam, namun pada ranah perlindungan masyarakat dan kepentingan penghormatan hak personal dan komunal.

\section{SA; Shalat Tamat}

Sakra Lombok Timur adalah bagian Lombok Timur yang banyak menganut paham kebatinan. Takpelak dari daerah ini muncul pemahaman yang sesat tentang ajaran Islam. Persoalan ini pun mencuat ke permukaan karena pemberitaan, baik oleh media lokal maupun nasional. SuaraNTB, Radio Lombok FM, dan media cetak nasinoal Republika menurunkan berita tentang kegaduhan akidah tersebut. 
Kasus dugaan penyebaran aliran sesat di salah satu desa di Gelumpang Kecamatan Sakra akhirnya berakhir di jalur mediasi. ${ }^{6}$ tidak mewajibkan shalat lima waktu beredar di daerah itu. Aliran sesat ini mengatakan bahwa shalat tidak wajib dikerjakan (shalat sudah tamat). Mereka memperbolehkan meminum minuman keras. Paham ini sudah menyebar di beberapa wilayah di kabupaten Lombok Timur, seperti di Sembalun, Sembelia, dan Sakra. Termasuk, di kabupaten Lombok Utara (KLU). Dalam menyebarkan aliran ini mereka menyasar anak-anak muda. Untuk menjaring jemaahnya para penyebar ini membagikan minuman keras secara gratis kepada mereka yang bergabung dalam aliran tersebut.

\section{Faham Transnasional}

Demikian potret ajaran Transnasinonal dan problem social yang menjadi ikutan atau konsekwensi keberadaannya. Berikut faham keagaamaan transnasional yang telah muncul di NTB.

\section{Ahmadiyah, Nabi Berbeda}

CNN sebagai media internasional juga takurung tergoda untuk melihat fenomena ajaran sesat dan beragam persoalannya. CNN Jakarta, Indonesia pada 30/06/2016 menurunkan berita dengan judul "Syiah Sampang dan Ahmadiyah NTB Jadi Prioritas Komnas HAM". Ahmadiyah juga ada di NTB. Kepengurusan Ahmadiyah di NTB terbentuk sejak tahun 1970. Sampai saat ini Ahmadiyah menjadi pekerjaan besar pemerintah daerah Nusa Tenggara Barat. Fatwa MUI / Dasar Hukum lain yang melarang No. 05/kep/munas II/MUI/1980 yang menyatakan ajaran tersebut sesat. Kemunculan Ahmadiyah adalah karena adanya pihak eksternal yang memicu. Pengaruh globalisasi dan informasi yang membawa paham-paham yang bertentangan dengan nilai-nilai Islam, juga menjadi bagian yang harus ditangani MUI NTB.

\section{Lembaga Dakwah Islam Indonesia, Nabi Berbeda}

CyberNews. Lombok Timur, menurunkan berita dengan judul "Jamaah LDII Mengungsi ke Pulau Jawa”. LDII adalah inkarnasi ajaran Islam Jama'ah, Darul Hadits yang telah difatwakan sesat. LDII (Islam Jama'ah) yang menganggap orang Islam di luar kelompok mereka "najis dan kafir". Fatwa Majelis Ulama Indonesia (MUI) Pusat bahwa ajaran Islam Jama'ah, Darul Hadits (atau apapun nama yang dipakainya) adalah ajaran yang sangat bertentangan dengan ajaran Islam yang sebenarnya dan penyiarannya itu adalah memancingmancing timbulnya keresahan yang akan mengganggu kestabilan negara. (Jakarta, 06 Rabiul

\footnotetext{
${ }^{6}$ http://www.suarantb.com/news
} 
Awwal 1415H/ 13 Agustus 1994M, Dewan Pimpinan Majelis Ulama Indonesia, Ketua Umum: K.H. Hasan Basri, Sekretaris Umum: H.S. Prodjokusumo.

Kemunculan faham keagamaan menyimpang di NTB dipandang dari sisi kemunculannya adalah bersifat lokalistik yang bersumber dari masyarakat awam pedesaan dan timbul sebagai kreasi interpretasi individual. Seluruhnya tidak menggunakan nama gerakan. Faham sesat ditandai dengan penyimpangan tutur tentang ketuhanan, kenabian maupun sumber hukum Islam. Faham sesat yang diajarkan mengekspketasikan adanya pengikut, seperti pada kasus $\mathrm{AB}$ dan SA. Adapun faham dan ritual sesat dalam kasus yang terjadi di desa SF Sintung adalah bentuk ritual kreasi yang tidak ada dasarnya dari ajaran Islam.

Melihat potret kemunculan kasus ini sesungguhnya membantah teori yang menyatakan bahwa munculnya paham yang menyimpang tidak lepas dari perkembangan sosial masyarakat yang cepat. Hal itu karena dalam kasus kemunculan ajaran (faham, ritual) adalah semata kreasi yang tidak di-pressure oleh perubahan sosial. Mereka para pencetus faham tersebut, lahir dan besar dalam suasana pedesaan dan tidak dipengaruhi oleh faham luar. Kasus ini juga menegaskan bahwa kemunculannya adalah karena interpretasi ajaran dan kreasi ritual.

Pandangan tentang kemunculan paham dan aliran dalam Islam sendiri disebabkan oleh eksternal (politik), juga tidak berlaku dalam kasus faham menyimpang di NTB. Kemunculan faham keagamaan baru lebih banyak pada aspek tafsir ajaran bukan kemunculan friksi politik dengan muatan tertentu. Benar, bahwa politisasi agama terendus dalam kehidupan beragama masyarakat NTB, namun hal itu tidak menjadi pemicu timbulnya faham baru. Politisasi agama adalah riak politik dengan bendera agama, dan bukan agama itu sendiri. Sementara ajaran sesat adalah agama (laten) dalam agama (mapan).

Faham menyimpang di daerah pedesaan disebabkan oleh faktor ekonomi. Demikian penuturan Ketua MUI. Meskipun pada narasi lain ada persoalan psikologis yang menjadi faktor utamanya. Pengakuan diri adalah salah satu faktor yang membuat orang untuk menjadi guru. Dalam hal ini guru dengan ajaran sesat. Pengakuan kesaktian, kedikjayaan maupun perilaku-perilaku aneh dapat menjadi daya tarik, sehingga masyarakat awam tertarik atau terpesona pada sang guru. "Tapi pada umumnya seperti tadi, orang-orang yang tidak punya ilmu itu orang-orang pinggiran. Itu kadang-kadang ada kelebihan yang dia miliki, misalnya kelebihan dalam retorika berbicara sehingga bisa mempengaruhi orang. Ini yang mudah sekali. Lalu, sedikit demi sedikit, dua tiga orang mulai diajak. Lama-kelamaan, orang-orang jadi ingin tahu. Lama-lama jadi ramai.” Demikian tutur Ketua MUI.

Motif ekonomi adalah motif penyebaran, sementara motif yang membuat kesesatan faham adalah faktor kedangkalan pemahaman agama. Sebagai anomali dari cara berfikir mainstream seringkali faham menyimpang menjadi menarik untuk diikuti. Tentu dalam konteks ini harus dibedakan antara motif (sebab) lahirnya faham sesat, motif penyebaran dan motif keberterimaan. 
Kemunculan aliran-aliran sesat dipengaruhi oleh faktor kurangnya pemahaman agama (lemahnya aqidah). Dengan kata lain, munculnya kesesatan karena kurang efektifnya dakwah atau lemahnya pembinaan umat beragama secara internal. Banyak pemimpin aliran sesat hanya memahami Islam secara parsial dan berani membuat sebuah langkah baru yang berbeda dengan ajaran aslinya. Di samping itu masalah ekonomi juga menjadi pemacunya. Cinta dunia membuat "jenuh yang memuncak" yang membutuhkan tempat pelampiasan.

\section{Fatwa Sesat; Reaksi MUI}

MUI NTB yang menangani kasus faham atau aliran sesat yang ditangani oleh suatu komisi khusus yang bernama Komisi Fatwa. Komisi Fatwa terkait dengan persoalan keagamaan dan tidak terkait langsung dengan hukum kenegaraan. Meskipun dalam penanganan selanjutnya MUI bekerjasama dengan kepolisian sebagai penegak hukum formil. Dalam konteks ini MUI tidak selalu bersama dengan pihak lain dalam penanganan faham sesat. Maka dalam kasus tertentu antar satu lembaga terkait sering tidak singkron dan terkesan tidak koordinatif. Fatwa hanya mengikat ke dalam dan tidak menjadi dasar bagi penegak hukum kenegaraan untuk mengambil tindakan hukum. Hal ini seperti ditegaskan oleh Ketua MUI NTB.

Menyoal keterlibatan lain dalam perumusan fatwa khususnya terkait dengan fatwa tentang aliran sesat, Ketua MUI menambahkan bahwa MUI bersifat inklusif terutama di Komisi Fatwa. Unsurnya adalah dari kalangan pelaku organisasi dan tokoh agama dan unsur akademisi yang dianggap ahli. Komposisinya terdiri atas 20-an orang. Pada prakteknya Ketua MUI tersebut menjelaskan bahwa tidak seluruh komponen yang terlibat dalam Komisi Fatwa dilibatkan dalam sidang-sidang terkait pemberian fatwa. Ia menyatakan bahwa hanya pada persoalan yang dinilai berat atau perlu kajian mendalam semua anggota komisi dilibatkan. Namun demikian salah seorang anggota Komisi Fatwa menandaskan bahwa mereka sama sekali tidak pernah dilibatkan dalam pengambilan keputusan terkait fatwa aliran sesat. Secara asumtif dapat disimpulkan bahwa tidak ada sidang khusus yang melibatkan seluruh komisi fatwa dalam hal penanganan faham sesat.

Eksistensi Komisi Fatwa juga dapat dilihat dari ketersediaan referensi yang digunakan dalam pengambilan keputusan. Hal ini penting mengingat pranata hukum dikonstruk dari referensi yang memadai. Berdasarkan observasi langsung, referensi yang digunakan terbatas pada referensi primer seperti Tafsir, Syarah Kitab Hadits dan kitab-kitab mu'tabarah lainnya. Tidak ada buku-buku khusus tentang aliran sesat kecuali referensi tentang aliran sesat yang sudah ditetapkan oleh MUI Pusat. Referensi yang kaya diperlukan mengingat varian aliran sesat membutuhkan kecermatan dalam penentuan sesat atau tidaknya pemahaman.

Adapun sidang-sidang yang dilakukan oleh Komisi Fatwa bersifat terbuka untuk berbagai persoalan keummatan. Tidak ada jadwal khusus dalam perumusan fatwa. Sidang 
tentang produk halal yang merupakan bagian dari tugas Komisi Fatwa paling banyak dilakukan. Dalam masalah penanganan aliran sesat MUI bersidang sesuai kebutuhan, meskipun sesungguhnya diharapkan ada tindakan lanjutan yang dilakukan sinergis oleh Komisi Fatwa dan komisi lain terutama di bagian dakwah dan penerangan. Tentu fatwa bersifat kondisional, reaktif, tetapi khusus untuk faham keagamaan harus ada penanganan lanjutan. Persoalan halal-haram pada produk makanan menyangkut aspek material, sementara paham menyangkut keshahihan pribadi sebagai seorang muslim.

MUI dalam pengambilan keputusan atau fatwa mengakui bahwa mereka juga melibatkan unsur non MUI. Seperti tokoh agama atau ahli pada bidang-bidang tertentu. Tentu saja semua di luar MUI. Jika mengacu pada apa yang disampaikan oleh Ketua MUI, pelibatan external MUI menggambarkan ekspansi MUI dalam pelaksanaan tugas-tugasnya, meskipun terlihat di satu sisi pihak internal MUI tidak maksimal melibatkan anggotanya. Hal itu dapat dipahami mengingat MUI adalah lembaga yang mengkaryakan orang dengan prinsip sukarela tanpa salary yang memadai. Optimalisasi hasil kerja MUI tidak dapat ditagih maksimal akibat terkendala pada aspek pembiayaan terutama dalam sidang-sidang yang bersifat insidentil.

Secara prosedural, MUI melakukan berbagai tahapan sidang. Hal itu disampaikan Saiful: "Kalau memang tidak bisa diselesaikan di sidang satu, maka akan dilanjutkan pada sidang berikutnya. Kalau tidak selesai di sidang kedua, kita akan lanjutkan ke sidang ketiga. Ketika sidang ketiga juga tidak selesai, maka kita akan teruskan menuju komisi fatwa MUI pusat. Tapi jarang itu. Itu prosedurnya."

Namun pada prakteknya tentang fatwa hukum lebih banyak mengadopsi fatwa di organisasi induk MUI yakni MUI Pusat. Demikian pula penanganan faham yang membutuhkan fatwa tidak selalu diputuskan dengan mekanisme pemberian fatwa, seperti pada kasus-kasus yang secara gamblang menggambarkan kesesatan faham. Pengakuan diri sebagai Nabi, ritual yang membolehkan hubungan dengan lawan jenis tidak memerlukan sidang khusus untuk menemukan fatwa tentang kesesatan. Namun demikian, persoalan fatwa adalah mekanisme mengembalikan keyakinan sesat menuju kebenaran. Jika fatwa tidak dikeluarkan, tidaklah menjadi persoalan. Yang ditagih sesungguhnya adalah bagaimana mekanisme untuk mengembalikan sang pelaku ajaran sesat pada jalan yang benar.

MUI diharapkan dapat melakukan tindakan preventif terhadap potensi menyebarnya ajaran sesat. Faham keagamaan yang sesat yang diyakini oleh perseorangan dapat berpotensi menjadi penyesatan jika sang pelaku mempengaruhi orang lain untuk mengikuti keyakinannya. Peneliti coba menelusuri apakah ada upaya pendataan bukan pada aspek praktek menyimpangnya, tetapi penelusuran potensi-potensi yang dapat mendorong timbulnya kesesatan dan penyesatan. 
Saiful mengakui tidak ada identifikasi atau pendataan yang memproyeksikan tumbuhnya faham yang menyimpang. "Kalau yang ini, kita tidak secara spesifik mendata itu. Tetapi, kita tetap memantau sehingga kita tidak membuat keputusan secepat itu. Kita tetap melihat perkembangannya di setiap MUI kabupaten kita juga tugasi untuk memantau tentang kegiatan keagamaan masyarakat. Apakah di sana ada terdapat hal-hal yang seperti tadi," demikian tutur Saiful.

Peneliti mengajukan persoalan ini mengingat ada kelompok lain yang fokus pada ajaran atau faham keagamaan. Mekanismenya bisa berangkat dari identifikasi faktor internal maupun eksternal timbulnya faham keagamaan. MUI diharapkan tidak berfungsi hanya sebagai pemantau. Hal ini karena ada pranata lain berupa lembaga yang bernama PAKEM. PAKEM dapat menjadi mitra MUI dalam melakukan pengawasan, tetapi MUI sebagai organisasi keulamaan harus mengambil peran yang lebih besar terutama peran dakwahnya.

Peneliti juga mengajukan pertanyaan apakah bentuk tindakan antisipasi faham atau gerakan menyimpang? Jawaban yang diperoleh hanya terbatas pada tindakan antisipasi terhadap ekses penyebaran faham tersebut. "Salah satunya, kita memberikan pemahaman/sosialisasi pada masyarakat kita untuk tidak mudah bertindak sendiri atau mengkafirkan orang lain. jadi, kalu dia betul-betul menyimpang, kita tunggu fatwa dulu", demikian tuturnya.

MUI mengakui bahwa lembaganya memberikan pemahaman maupun sosialisasi sebatas pada tindakan untuk menghindari konflik di tengah-tengah masyarakat akibat pro-kontra suatu faham atau ajaran baru. MUI mengingatkan agar pihak yang tidak setuju dengan suatu faham kegamaan yang menyimpang, untuk tidak mengambil tindakan main hakim sendiri. MUI juga mengingatkan bahwa labeling cap kafir ataupun murtad tidak menjadi otoritas personal, tetapi penentuan status keyakinan menyimpang menjadi wilayah kerja MUI. Artinya tidak ada tindakan antisipasi untuk meminimalisir munculnya faham atau gerakan yang menyimpang. MUI bekerja secara reaktif.

MUI juga mengakui bahwa faham-faham menyimpang sangat jarang terjadi. Hal ini berbeda dengan hasil cross-cek melalui media massa. Media terutama media cetak selalu mempublikasikan ajaran-ajaran yang menyimpang. Hampir tiap tahun selalu ada publikasi tentang ajaran yang menyimpang. Tahun 2015, 2016, 2017 faham keagamaan yang terpublikasi media sifat dan karakteristik beragam. Namun demikian, selalu ada faham keagamaan yang muncul baik di perkotaan maupun di pedesaan. Penyimpangan faham bukan saja oleh masyarakat dengan minus pemahaman keagamaan, melainkan juga oleh mereka yang memiliki pengetahuan yang memadai.

MUI mengakui bahwa pengaruh eksternal juga menyebabkan menyimpangnya fahamfaham keagamaan masyarakat. Gerakan-gerakan trans-nasional yang demikian masive memberikan penetrasi ke tengah-tengah masyarakat dengan dalih bantuan untuk masyarakat 
miskin nyatanya mendapat tempat yang luas di tengah-tengah masyarakat. Pada kasus-kasus berkembangnya ajaran salafi misalnya, motif ekonomi membuat calon pengikutnya tertarik dan merasa nyaman menjadi anggota kelompok tersebut. Demikian pula gerakan Ahmadiyah, motif ekonomi yang ditawarkan oleh organisasi tersebut membuat pengikut jamaah ini tetap bertahan meskipun sudah dikucilkan.

$\mathrm{AB}, \mathrm{SF}, \mathrm{KH}$ adalah representasi kemiskinan di pelosok negeri yang mengaku Islam dengan pemahaman yang minimal. Kemiskinan ekonomi dan kemiskinan pengetahuan agama membuat mereka rentan untuk dirasuki ajaran sesat meskipun itu dari hasil kontemplasinya. Berbeda dengan kasus ajaran sesat transnasional yang konstruknya mapan dan memiliki argumen yang kuat meskipun tentu menyalahi paham mainstream.

Ahamdiyah dan LDII adalah produk gejala sosio-politis, ketimbang sebagai sebuah gejala keagamaan murni. Secara sosiologis, bermunculan banyak aliran sesat dan fenomena masyarakat mudah "percaya" dengan gejala janji-janji yang instan. Pengaruh globalisasi dan informasi membawa paham-paham yang bertentangan dengan nilai-nilai Islam.

\section{Kesesatan dan Dakwah Strategik MUI}

Peran pemberdayaan ummat MUI memiliki komisi yang relatif lengkap menyasar seluruh aspek kehidupan masyarakat. Secara khusus ada komisi dakwah di dalamnya dan komisi terkait dengan ajaran sesat. Struktur yang kaya menandakan bahwa MUI dibentuk dengan hajat agar seluruh kepentingan negara dapat disalurkan melalui lembaga yang kaya ini. Hirarki struktur menandakan bahwa sistem organisasi telah disusun secara sistematis mulai dari level pusat sampai di kecamatan. Namun demikian tampaknya pada aspek dakwah MUI tidak selalu melakukan aktivitas secara masif-terstruktur. Ada indikasi bahwa MUI bergerak secara insidentil. Hal itu terlihat dari jawabn tentang intensitas pertemuan internal MUI. "Intensitas pertemuan pihak (intern MUI NTB) yang terlibat dalam kajian faham sempalan itu tergantung. Sewaktu-waktu. Sesuai dengan kebutuhan. Jadi, kalau kebutuhannya mendesak, maka kita lebih intens melakukan kajian." Demikian tuturnya.

MUI bergerak jika muncul persoalan. Pada aspek dakwah MUI bekerja secara reaktif hal ini dapat dilihat bahwa MUI dalam memberdayakan anggotanya masih mengandalkan sumber daya personal bukan kekuatan komunal. Hal ini dapat dipahami karena para tuan guru dan ustadz yang notabene-nya menjadi anggota MUI telah memiliki "pekerjaan sendiri" dalam melakukan dakwah islamiyah. Apalagi di Nusa Tenggara Barat tumbuh subur organisasi Islam di masyarakat dan menjamurnya pondok pesantren serta lembaga Islam lainnya.

MUI sesuai perannya sesungguhnya dapat berfungsi sebagai suprasistem yang dapat mengkaji persoalan agama secara makro. Hasil konstruksi kajian itu dapat dijadikan sebagai acuan dalam menyusun sistem dakwah yang komprehensif dan integratif. MUI juga dapat melakukan meta-analisis terhadap persoalan dakwah termasuk di dalamnya analisis kritis 
terhadap keberhasilan dan kegagalan dakwah di Nusa Tenggara Barat. MUI dapat berperan sebagai lembaga kontrol yang bergerak secara leluasa pada ranah pemberdayaan dakwah. MUI harus memotret realita dakwah termasuk potensi masuknya aliran sesat dan menghitung ulang implikasi hadirnya ajaran-ajaran baru yang meresahkan masyarakat.

Salah satu kajian menarik meskipun tentu bersifat personal adalah kajian ketua MUI NTB tentang bagaimana proses infiltrasi ajaran "asing" ke dalam masyarakat NTB. Beliau menilai bahwa ajaran atau paham baru yang masuk ke NTB banyak memanfaatkan lemahnya tata kelola masjid sekaligus rendahnya animo masyarakat untuk memakmurkan masjid. Beliau secara gamblang menjelaskan bagaimana aneksasi masjid oleh orang luar komunitas masjid sehingga aktivitas keagamaan tidak dikuasai oleh jamaah sekitar. Beliau meyakini bahwa (penguasaan?) masjid adalah jalur masuk bagi munculnya paham keagamaan yang dianggap alien.

Beliau mengeritik bahwa animo membangun masjid masyarakat Lombok pada khususnya tidak selaras dengan animo memakmurkannya. Membangun masjid telah bergeser dari kebutuhan ibadah ke arah tendensi apresiasi simbolik yang berular kebanggaan (kesombongan). Masyarakat Lombok berkejaran dengan waktu dalam perlombaan megahmegahan tempat ibadah. Kritik ketua MUI tersebut sekaligus bentuk kerisauannya rupanya adalah realitas sosial yang membuka akses bagi penguasaan situs keagamaan oleh penganut kepercayaan dari luar kawasan.

Persoalan aneksasi dan kolonialisasi rumah ibadah berikut gerakan penyesatan oleh "orang baru" merupakan persoalan emergent dan kritis. Perenungan beliau alangkah indahnya jika menjadi titik risau dalam mewacanakan realisasi-aksi dakwah dan tagihan parameter keberhasilannya. Diharapkan ada pemetaan pola pergerakan dan potensi timbulnya aliran sempalan disusun cermat melalui kajian dakwah komprehensif.

Dalam penanganan paham sesat yang berpontensi mengakibatkan (menyebabkan) disharmoni sosial MUI telah melakukan upaya untuk aktif. MUI telah melakukan mediasi untuk mengembalikan pengikut ajaran sempalan untuk kembali pada kepercayaan mainstream. MUI juga sudah melibatkan lembaga atau kelompok mitra dalam menangani persoalan yang berpotensi konflik. Unsur-unsur MUI juga turun gunung dalam menangani kelompok sempalan dan melibatkan mitra dalam penanganannya.

Sayangnya MUI tampaknya menyerah ketika sekelompok orang tersebut tidak berkenan mengikuti arahan dan petunjuk pemerintah. MUI sekaligus pemerintah tampaknya menyerah dan terkesan membiarakan eksisnya kelompok yang berindikasi sesat bertahan di wilayah hukum Nusa Tenggara Barat. Pemerintah daerah juga tampaknya tidak mampu ditekan oleh MUI untuk mengambil keputusan dalam penangan persoalan secara berkelanjutan.

Tampaknya aliran yang berasal dari luar dan bersifat transnasional lebih memilih taat kepada "majikan" mereka dan tidak taat kepada pemerintah dimana mereka tinggal. Dalam 
konteks ini sikap mereka dapat dikategorikan sebagai tindakan pembangkangan yang dapat dipertimbangkan hak-hak kewarganegaraannya. Tentu paham-paham yang timbul secara personal-lokal relatif lebih mudah ditangani meskipun dalam kasus-kasus ajaran yang sudah kadung banyak pengikutnya MUI harus berkerja ekstra.

Persoalan ini Ahmadiyah juga mempertegas organisasi yang berasal dari luar NTB. Itu pula yang menjadi perhatian MUI. "Kita selalu bersama-sama pemerintah. Dalam kasus GAPATAR, yang pernah terusir dari Kalimantan. Orang sini (Lombok) dipulangkan ke sini. Sebelum mereka dipulangkan ke tempat keluarganya, mereka terlebih dahulu ditampung di sebuah penampungan milik Dinas Sosial. Kita pergi ke sana, penampungan itu, berdialog dengan mereka. Tetapi, mereka tidak mau berubah.” Demikian tutur beliau.

Secara asumtif persoalan lokal dapat dilokalisir dan diminimalisir inflikasi sosialnya dibandingkan dengan paham yang bersifat komunal-global. Di sinilah tepat pembacaan MUI dalam pencarian model konstruksi dakwah yang tepat sasaran.

Ditinjau dari perspektif dakwah stuktural MUI telah melakukan tindakan proaktif dengan mengajak Pemda terutama Dinas Sosial untuk mengurus persoalan yang timbul akibat keluarnya fatwa sesat. MUI juga melibatkan struktur yang lebih randah di bawahnya seperti MUI Kabupaten. Keterlibatan mitra tersebut secara langsung terjun ke masyarakat. Peneliti menanyakan tentang apakah MUI turun lapangan untuk investigasi (penyelidikan) praktek pemahaman sempalan? Beliau menjawab: "Iya, kita investigasi. Tidak hanya kepada yang bersangkutan tetapi juga kepada masyarakat sekitarnya. Yang biasa kita lakukan adalah bersama dengan MUI tingkat kabupaten/kota."

Sayangnya keterlibatan mereka lebih mengarah ke dalam pemberdayaan dalam aspek sosial. Sementara paham agama tak terselasaikan meskipun melibatkan Pemda sebagai mitra MUI. Harus ada solusi alternatif bagi persoalan-persoalan yang tak terselesaikan dengan satu pendekatan saja. Persoalan keimanan adalah persoalan hitam putih dan penanganannya tidak bias dengan satu pendekatan saja. Di sinilah diperlukan lembaga mitra yang konsen tehadap dakwah Islam.

Untuk menangani persoalan hukum akibat timbulnya fatwa sesat MUI melibatkan kejaksaan, intelegen daerah dan tentu Pakem. Tiga mitra keja MUI ini bekerja sesuai kapasitasnya masing-masing. Bahkan pemerintah mengakui bahwa MUI adalah mitra pemerintah dalam pembangunan dan tidak terbatas pada aspek keagamaan saja.

Peneliti juga mempertanyakan spesifikasi penaangan kasus keagamaan yang menyimpang diperoleh keterangan bahwa hal itu sesuai dengan kasus yang dihadapi. Artinya, tidak ada pembagian sebelumnya. "Yang bertugas ini ini ini, tidak ada", tutur Muslim . Hal itu tergantung kepada permasalahan yang dihadapi. Setiap permasalahan yang dihadapi, pasti dicarikan ahlinya di bidang itu. 
Sebagai lembaga pemerintah dengan kemitraan yang jelas, MUI NTB juga melibatkan ormas semisal Nahdlatul Wathan, Nahdlatul Ulama, dan oramas Islam lainnya. Biasanya melibatkan semua ormas besar dalam diskusi maupun dalam kajian, meskipun tidak dilibatkan di seluruh siding fatwa. Hal itu karena fatwa menjadi otoritas kelembagaan bukan hasil keputusan sidang terbuka dengan pelibatan personal dan ormas di luar MUI. Diakui Ketua MUI, bahwa mereka dilibatkan dalam penanganan faham sempalan. "Karena pasti ada kaitannya dengan yang tadi itu", imbuhnya. Semua tokoh agama, perwakilan ormas, semua dilibatkan. Tergantung pada kebutuhan ilmu dan pokok bahasan yang akan dibahas. Yang dilibatkan adalah terutama para Tuan Guru kita yang sudah ahli dengan kitab-kitab klasik.

Dakwah otoritatif yang dijalanakn MUI menjadi bagain yang menarik untutk dicermati mengingat otoritanya yang demikian kuat dan mampu melibatkan beragam pihak dari beragam kalangan. MUI adalah lembaga besar dan mapan. MUI NTB memiliki kemandirian dalam menyelesaikan persolan faham atau aliran sesat dan berbagai persoalan lainnya. MUI NTB jarang melibatkan (baca: meminta fatwa) dalam mengambil keputusan di wilayah atau bidang tugasnya.

MUI pusat tidak dilibatkan secara langsung. Tetapi, ketika ada keputusan yang tidak bisa diambil kesepakatan bersama di sini (MUI NTB), maka diangkat ke MUI Pusat. Tetapi, sepanjang itu bisa diselesaikan di sini, maka hanya menyampaikan hasil saja ke MUI Pusat. Gambaran ini mengindikasikan kemandirian MUI dalam penanganan kasus kasus keagamaan dan persolan sosial.

Dilihat dari sumber pengambilan keputusan atau acuan normatifnya, acuannya adalah acuan pokok dalam dakwah islamiyah. Demikian pula sumber-sumber kitab kklasik yang masih dipercaya oleh MUI sebagai sumber rujukan primer di samping kriteria yang dibuat oleh MUI pusat.

Penetapannya, dikaji dulu dengan kitab-kitab yang ada dengan keahlian masing-masing. Kemudian sidang. Setelah ada kesepakatan, baru disusun seperti apa fatwanya. Fatwanya berdasarkan Al-Qur'an, Hadits, kaidah-kaidah fiqih. Masuk juga di dalamnya kaidah-kaidah Undang-Undang. Intinya, mulai dari Al-Qur'an, Hadits kemudian pendapat para ulama. Setelah itu barulah ada keputusan.

Untuk publikasinya, dilakukan sesuai dengan kebutuhan juga. Yang penting sudah ditetapkan fatwa, setelah itu baru disampaikan kepada siapa yang meminta. Kalau ada yang bertanya, baru dikeluarkan. Di antara cara MUI mempublikasikannya yaitu dengan membuat buku-buku kecil yang kemudian dicetak. MUI mencetak dalam bentuk buku-buku kecil, kemudian itu disebarkan melalui MUI tingkat kabupaten/ kota.

Sosialisasi menggunakan media dilakukan oleh MUI mengingat tidak seluruhnya bisa didatangi langsung dan mereka telah melek huruf. Sayangnya MUI masih menganggap upaya pembinaan ummat termasuk di dalamnya proses penyadaran kembali menjadi otoritas 
pemerintah, meskipun tentu MUI adalah lembaga bentukan pemerintah. "MUI menyampaikan kepada umat Islam. Hanya pada masalah fatwa. Kalau sudah ke ranah pelarangan atau hukum, itu sudah urusan pemerintah", Tutur Muslim.

MUI memiliki struktur yang lengkap meliputi berbagai aspek sosial keagamaan. Namun demikian keberfungsian masing-masing komisi tersebut masih perlu dipertanyakan. Demikian pula relasi dan koordinasi antar komisi. Dalam banyak kasus, MUI menangani kasus-kasus paham sempalan yang dilakukan oleh perorangan dari unsur MUI, tidak dilakukan secara kolektif di internal komisi. Demikian pula koordinasi antar komisi tidak ditekankan. MUI kaya struktur, miskin fungsi. Dakwah-dakwah yang bisa dilakukan secara kolektif dengan satu bahasa yakni kebersamaan akan lebih mudah ditangani. Demikian pula halnya jika dilakukan dengann multi-kanal multi perspektif.

MUI merupakan wadah berkumpulnya para ulama yang memiliki kredibilitas dan kapasitas keilmuan untuk memberikan penilaian terhadap ajaran tertentu. MUI menjadi rujukan persoalan keummatan yang bersifat multidimensi. MUI dipercaya untuk berkarya dalam dakwah nyata. MUI semestinya merisaukan apakah benar bahwa dakwah umat Islam yang berada di luar kekuasaan adalah dakwah yang tidak lengkap dan sempuma (kaffah).

\section{Penutup}

Setelah melakukan kajian, baik melalui studi di lapangan maupun studi literatur, maka dapat diambil beberapa kesimpulan sebagai berikut. Pertama, faham sesat di NTB, muncul hampir setiap tahun baik aliran transnasional yang berciri sosio-politik maupun lokal berciri sosio-ekonomis yang muncul sebagai konstruksi personal-awam melalui proses kontemplasi batin. Kedua, faham sesat transnasional maupun lokal ditangani responsif secara koordinatiftentatif oleh beberapa komisi di MUI dan kerjasama dengan jajaran pemerintah daerah maupun MUI Pusat. Ketiga, dakwah struktural yang massif dan memaksimalkan seluruh unsur MUI dan mitra kerja MUI belum digarap dengan baik dengan multipendekatan, multi-kanal dan professional.

\section{Daftar Pustaka}

al-Bayânûnî, Muhammad Abû al-Futûh. al-Madkhalilâ 'ilm al-Da'wat. Beirut: Mua'ssasat alRisâlat, 1991.

Bakti, Andi Faisal. Communication and Family Planning in Islam in Indonesia; South Sulawesi Muslim Perception of a Global Development Program. Leiden-Jakarta: INIS, 2004.

Baron dan Sukidin. Metode Penelitian Kualitatif Perspektif Mikro. Surabaya: Penerbit Insan Cendikia, 2002.

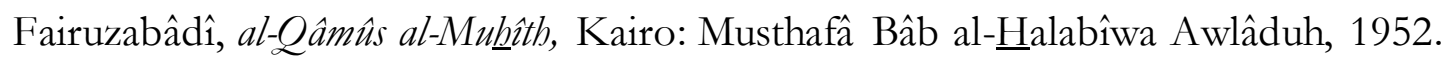




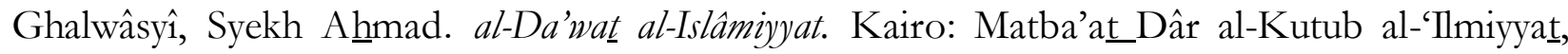
t.th.

Husayn, Muhammad al-Khaydar. al-Da'watilâ al-Islâh. Kairo: Maktabat al-Azhar, t.th.

Ibn Manzûr, Lisân al 'Arab (Beirut: Matba'at_Dâr al-Fikr, 1990 M/1410

Jurnal Analisis 13, no 2 (Desember 2013). http://moraref.or.id/record/view/22869

Madjid, Nurcholish. Dorongan dan Hambatan Kultural bagi Kerukunan Umat Beragama di Indonesia, Musyawarah Nasional Cendekiawan Antar Agama. Yogyakarta, Januari 1996.

Moleong, Lexy J. Metodologi Penelitian Kualitatif. Bandung: Remaja Rosdakarya, 2000.

Nasution, Harun. Teologi Islam, Aliran-aliran Sejarah Analisa Perbandingan. Jakarta: Penerbit Universitas Indonesia, 2008.

Nuh, Nurhison M. Aliran/paham Keagamaan dan Sufisme Perkotaan. Jakarta: Departemen Agama RI badan Balitbang dan Diklat Puslitbang kehidupan Keagamaan, 2009.

Salam, Syamsir dan Jaenal Aripin. Metodologi Penelitian Sosial. Jakarta: UIN Jakarta Press, 2006. Zakariyyâ, Abû Bakar. al-Da'watilâ al-Islâm. Kairo: Matba'at Maktabat Dâr al-'Arûbat, 1962. 